\title{
Honesty in Language in Special Fugitive Scandal: Forensic Linguistic Studies in Broadcasting Talks Indonesia Lawyers Club
}

\author{
Muhammad Musawir ${ }^{1}$, Johar Amir ${ }^{1}$, Muhammad Saleh ${ }^{1}$ \\ Corresponding Email: muhammadmusawir01@gmail.com \\ ${ }^{1}$ Language Education Study Program, Postgraduate Makassar State University, Indonesia \\ Received: January 21, $2022 \quad$ Received in Revised: February 16, $2022 \quad$ Accepted: February 28, 2022
}

\begin{abstract}
Forensic linguistics as a branch of linguistics that analyzes and examines language in legal products, legal processes, and legal evidence still needs to be improved in Indonesia, especially the study of language honesty in crime cases. Therefore, it is important to continue the study of forensic linguistics. This study aims to describe the veracity language in the special fugitive scandal. This research is a type of qualitative research with a descriptive qualitative research design that focuses on analyzing the level of veracity in language in the special fugitive scandal using John Olsson's Statement Analysis in Linguistic (SAL) model. The data of this research are oral data, namely forensic text narratives contained in talk shows about special fugitives. The data source in this research is the Indonesia Lawyers Club (ILC) talk show. The main theory used in this research is the study of forensic linguistics which is specified in John Olsson's theory of veracity language. The results of this research indicate that veracity in language in special fugitive scandals tends to have a high level of veracity.
\end{abstract}

Keywords: Forensic Linguistics, Veracity In Language, Special Fugitive, Indonesia Lawyers Club

\section{Introduction}

In Indonesia, corruption is one of the extraordinary crimes. Corruption is called an extraordinary crime because the proof is very difficult and the impact is very broad, namely it can damage the joints of the country's economy. Massive and structured corruption can hamper the country's economic growth, even in some cases it can cause people in the country to fall into poverty. Seeing the urgency of this corruption case in Indonesia, it is important to study it scientifically, one of which is through forensic linguistics, especially language honesty.

One of the corruption cases that has attracted a lot of attention in Indonesia is the corruption case of transfer of claim rights (cessie) of Bank Bali involving the name of a businessman, DT. Reporting from various sources, it is no exaggeration if DT is called a special fugitive. The reason is that DT's return to Indonesia after eleven years on the run has caused a stir in this country. The convict of the Bank Bali claim rights (cessie) case that cost the state up to Rp940 billion was easy to access a number of public services, ranging from taking care of an electronic ID card, extending a passport, taking care of the administration of the case review (PK), getting a travel document, to getting a Covid-19 free letter. is an illustration of how special the treatment of this top class fugitive is. The passage of DT freely shows that this fugitive from a corruption case is treated with special privileges.

The series of events immediately angered a number of people, including the Coordinating Minister for Politics, Law and Security, Mahfud MD. According to him, the arrest of DT should be a trivial matter so it would be outrageous if the Police and the Attorney General's Office could not arrest him. Member of Commission III of the DPR RI, Taufik Basari, also responded 
to this. According to him, this incident involved a network that was carried out by many parties. DT is not alone, there are many parties behind it. A series of questions deserve to be asked to the relevant institutions about this scandal. To the Immigration, don't they know that DT passes at the airport? To the Dukcapil party who served DT in making electronic ID cards, did they not recognize DT as a fugitive? To the Attorney General's Office who is the main executor, are they completely blind to the maneuvers of this most wanted fugitive? Questions are also appropriate to ask the Ministry of Foreign Affairs. Don't they smell DT's movements in Malaysia and Papua New Guinea?

A number of talk shows on television were also busy raising the theme of the DT case. One of the most popular talk shows in Indonesia is the Indonesia Lawyers Club (ILC). The ILC, which was guided by a senior journalist, Karni Ilyas, discussed the case in one of its episodes, with the theme Simsalabim Djoko Tjandra which aired on July 7, 2020. The sources or public figures involved in the ILC discussions included the DT lawyer, the Director General of Migration, Ministry of Law and Human Rights, RI, Director General of Department of Population and Civil Registration, Ministry of Home Affairs RI, as well as a number of other resource persons. However, did these sources or public figures provide honest information or did they try to cover up the facts on the ground so that public suspicions that DT was assisted by a number of parties were not exposed? For this reason, the author is interested in examining the veracity of the narratives of the informants presented on the ILC talk show from the aspect of forensic linguistics. The author's interest in researching this topic is also based on the lack of research or studies on language honesty from the forensic linguistic aspect carried out in Indonesia. In fact, if you look at the phenomenon of language in Indonesia today, many have led to criminal acts or violations of the law. Therefore, forensic linguistics is deemed necessary to get more attention.

\section{Theory}

\section{Forensic Linguistics}

Forensic linguistics is a combination of two disciplines, namely linguistics and forensic science. Linguistics is the science of language, while forensics comes from the Greek term forensis which means public or forum. In the Roman political tradition, a forum was a public space that became a place to discuss and debate political and policy issues. In its development, forensic science has become a science that is used to help answer scientifically about evidence related to law enforcement. In other words, forensic linguistics is a multidisciplinary science that can be used to solve a criminal problem (Rahmat, 2017; Galyashina, 2018; Walters, 2020; Ali, 2020).

The evidence found after a crime is not only in the form of non-language evidence, such as weapons, surveillance camera recordings, fingerprints, etc., but can also leave evidence in the form of language (both spoken and written), so for the purposes of proof whether the language found can be evidence for the criminal case requires a scientific study. The results of scientific studies of language in relation to law enforcement are known as forensic linguistics (Mahsun, 2018). Forensic linguistics (forensic linguistics) is the science of linguistics that is applied for forensic purposes, which is related to legal language, legal contexts, legal texts, and courts (McMenamin \& Choi, 2002). In line with the opinion above, Olsson \& Luchjenbroers (2014) also state that forensic linguistics is a branch of linguistics that analyzes and examines language used as a tool of evidence in court and law.

\section{Honesty in Language}

In forensic linguistics, honesty in language is closely related to the question "true or wrong?" which basically applies to witnesses of a particular case. There are several techniques that can 
be used to measure honesty, one of which is SVA (Statement Validity Analysis). SVA is more dominant in the psychological aspect, which is the key to this technique is memory. In addition to the psychological aspect, it can also be traced from the linguistic aspect to determine language honesty, what has been known as Statement Analysis in Linguistics (SAL). This approach differs from SVA in that it is not based on aspects of memory, fantasy, honesty, and truth. This linguistic approach is more focused on topics related to aspects of narrative structure, sequence of events, and association of narrator with events.

\section{Methods}

This research is a qualitative research with a qualitative descriptive design as a form of understanding and objective development. The data of this research are oral data, namely forensic text narratives contained in talk shows about special fugitives. The data source in this study is the Indonesia Lawyers Club (ILC) talk show. Data collection techniques in this study used the SBLC technique (Listen Free Libat Cakap) and note-taking techniques. According to (Sudaryanto, 1993), in using this SBLC technique, researchers are not directly involved in dialogue, conferences, or exchanges; so do not participate in the process of talking people talking to each other. The research instrument is a data collection tool in a study (Meleong, 1989). The instrument used in this research is that the researcher himself acts as a human instrument (planner, data collector, data interpreter, data analyzer, and report on research results). In addition to these research instruments, there are two other research instruments used in this study, namely data reduction instruments and data analysis instruments.

\begin{tabular}{|c|c|c|}
\hline Stage I & Stage II & Research Focus \\
\hline Types of Forensic Text & $\begin{array}{l}\text { Research Focus } \\
\text { Elements }\end{array}$ & \\
\hline \multirow{3}{*}{$\begin{array}{ll}\text { - } & \text { Confession } \\
\text { - } & \text { Denial }\end{array}$} & $\begin{array}{l}\text { - Subject } \\
\text { - Predicate } \\
\text { - Time } \\
\text { - Place }\end{array}$ & Narrative Structure (NS) \\
\hline & - Order of Events & Sequence of Events (SE) \\
\hline & $\begin{array}{l}\text { - Description/Details } \\
\text { - Pronominal } \\
\text { Redirection }\end{array}$ & $\begin{array}{l}\text { Association of Narrator } \\
\text { with Events (ANE) }\end{array}$ \\
\hline
\end{tabular}

Data Reduction Instruments (Olsson: 2008)

\section{Results and Discussion}

In this section, the results of the research in the form of forensic texts are described in detail with a focus on the honesty of the language of public figures in the special fugitive scandal.

\section{Honesty in Language Based on Narrative Structure Aspects in the Special Fugitive Scandal}

Through the identification and classification process, the results of data analysis show that there are types of forensic texts in the form of confessions and denials, both in the category of narrative subject, predicate, time, and place, which were carried out by public figures involved in the special fugitive case based on the narrative structure aspect.

In several forensic text narratives in the special fugitive scandal, there are several types of forensic texts with a high degree of honesty based on the narrative structure aspects presented in the data (1). The data shows that there are categories of places in Anita Kolopaking's confession narrative. 
In one of the narratives of her confession on the Indonesian Lawyers Club talk show, Anita Kolopaking as a DT lawyer explained that the reason her client did not attend the Judicial Review (PK) trial was because her client was sick. Karni Ilyas as the host of the ILC discussion then asked whether DT had a sick certificate or not. Anita also replied that her client had a sick certificate and it had been submitted to the panel of judges. Then, Karni Ilyas continued the question, where did DT get the letter and Anita answered that her client got the letter at a hospital clinic in Malaysia. It can clearly be seen in data (1) below.

(1) Karni Ilyas: Any letters?

Anita K.: There's a letter. We delivered in.

Karni Ilyas: From which hospital?

Anita K.: Clinic in ru.. in Malaysia, Pak. In Kuala Lumpur. Clinic, hospital clinic. There, really. We've told the judge.

The narrative above is said to be a confessional narrative because there was a confirmation answer from Anita Kolopaking and did not dispute what was asked by Karni Ilyas. In the confessional narrative above, Anita Kolopaking answered Karni Ilyas's question spontaneously, namely There was a letter. Then, when asked again where DT got the letter, Anita again answered with simple details, which only mentioned hospital clinics in Malaysia. Without any excessive and long-winded details, for example to mention the name of the clinic or the detailed address of the clinic. This shows the high commitment of the narrator in conveying the narrative of his confession. That is, the narrator does not show any indication of falsehood in the narrative of his confession. In other words, the honesty level of Anita's confessional narrative is high.

In addition to narratives with a high level of honesty in the special fugitive scandal, there are also several types of forensic texts of confessions with a low level of honesty based on the narrative structure aspect shown in data number (2). The confession narrative data in number (2) can be analyzed in the subject category. This can be seen through the omission of the subject by Anita Kolopaking in her narration.

When DT's lawyer, Anita Kolopaking, explained that she had previously been called by her client to discuss the plan to make her e-KTP, Karni Ilyas as a talk show host for the Indonesia Lawyers Club asked Anita whether at that time DT was already in Indonesia or not. Hearing this question, Anita seemed to think for a moment before giving an answer. At that time, sir. Karni Ilyas then continued to ask, Oh still abroad? and immediately answered very briefly by Anita Kolopaking with one word, Yes.

(2) Karni Ilyas: That, Mom by the way Mr. Djoko Tjandra is in Jakarta, already?

Anita K.: It wasn't, sir.

Karni Ilyas: Oh, still abroad?

Annita K.: Yes.

The confession in the narrative above is marked by Anita Kolopaking's answer when answering Karni Ilyas's question, "Not yet, sir. This means that Anita admits that her client is still abroad when she talks to her on the phone. The confessional narrative does not appear to have a good structure, that is, it does not include the subject in the sentence. For example, why didn't Anita say that at that time, Mr. DT was not yet in Indonesia, sir. or At that time, he was not in Indonesia, sir. Anita's omission of the subject, whether intentionally or unintentionally, indicates doubt. Furthermore, when asked again by Karni Ilyas Oh, are you still abroad? Anita again gave a very short but not firm answer, Yes.

Copyright ( 2022, Journal of Asian Multicultural Research for Social Sciences Study, Under the license CC BY-SA 4.0 
Through that analysis, it appears that Anita Kolopaking did that because she wasn't really sure about her own words.

In addition to several confessional narratives in the special fugitive scandal, there are also several denial narratives with a high level of honesty based on the narrative structure aspect shown in data number (3). In narrative data number (3), Anita Kolopaking denies that she and her client finished making e-KTPs before 8.30.

While telling how she accompanied her client to make an e-KTP in the Indonesia Lawyers Club talk show, Anita Kolopaking denied the information that she and her client finished making e-KTP before 8.30. Anita said that she did not know exactly when they left the Grogol Selatan Lurah Office. Then, Karni Ilyas as the host of the event conveyed information that they arrived at the South Jakarta State Pendilana at 8.30. Anita immediately denied it, saying she was not sure that they arrived at 8.30am at the South Jakarta District Court. Anita again continued that according to her recollection, it was around 9. It can clearly be seen in the data number (3) below.

(3) Anita K.: So, I don't know exactly what time I left. Just now, I said that it's time.

Karni Ilyas: 8.30am has arrived at the South Jakarta Court.

Anita K.: I'm not sure, sir, that clock. As far as I know it isn't. I reme mber about 9 o'clock. All I remember is, yes, sir.

In the denial narrative above, making a rebuttal marked by the phrase I don't know, I'm not sure, and as far as I know it's not. DT's lawyer, Anita Kolopaking, denied the allegation that she and her client finished making e-KTPs before 8.30 in reasonable detail, by saying that they did not know exactly what time they left the Grogol Selatan Lurah Office. Then, Karni Ilyas continued that Anita and DT were found to have arrived at the South Jakarta District Court at 8.30. Anita again categorically denied the accusations and said that according to her memory, it was not 8.30, but around 9. The time information in the denial narrative made by Anita Kolopaking had simple details. Anita does not provide excessive details or descriptions, for example at 9.10, at 8.55, and so on. This shows the high commitment of Anita Kolopaking in making her denial narrative.

In addition to the narrative of denial with a high level of honesty in the special fugitive scandal, there is also a type of forensic text of denial with a low level of honesty based on the narrative structure aspect shown in data number (4). In narrative data number (4), it is shown that there is a predicate category in Anita Kolopaking's denial narrative. This is reflected in the incomplete sentence structure due to the absence of a predicate.

When explaining the process of making the e-KTP DT accompanied by herself, Anita Kolopaking said that what she was doing was something natural and should not be twisted in a wrong direction. Then, hesitantly Anita continued with an unfinished fifth.

(4) Don't be twisted as if I'm facilitating. It's not my KTP business... (Anita Kolopaking)

In the denial narrative above, Anita Kolopaking denies the allegation that she facilitated DT in making the e-KTP. This can be seen from the clause Don't twist it as if I were the one facilitating it. Anita then said that her involvement in the processing of the DT-elKTP was nothing more than a lawyer, so there was no need to twist it as if she was facilitating it. It didn't stop there, Anita continued her sentence again. However, he did not finish the sentence so that the sentence structure of the narrative was incomplete or not predicated. At first glance, there is nothing strange about the narrative. However, if you look closely, this creates an awkwardness, as if Anita had doubts about what she wanted

Copyright $\odot$ 2022, Journal of Asian Multicultural Research for Social Sciences Study, Under the license CC BY-SA 4.0 
to say, so she canceled her intention to continue her sentence. In fact, he could have continued his sentence freely because at that time no one interrupted his conversation, instead he continued his discussion without finishing the sentence. Although this category is rare, it is in line with Olsson's opinion that the omission of a sentence's function in a narrative is an indication of a distance feature, meaning that the narrator is not sure of his own words.

\section{Honesty in Language Based on Sequence of Events in Special Fugitive Scandal}

In several forensic text narratives in the special fugitive scandal, there is a forensic text type of confession with a high level of honesty based on the aspect of the sequence of events shown in data number (5). In data number (5), it is shown that there is a sequence of events in the narrative of Joni Ginting's confession. This is reflected in the chronology presented in the narrative.

In the Indonesia Lawyers Club (ILC) talk show, Joni Ginting explained about the entry of DT into Indonesia and the process of making his passport. Joni explained the chronology from the issuance of DT's passport until it was withdrawn. Joni explained that DT's passport was completed and issued on the 23rd and then withdrawn on the 27 th. The Immigration Service visited DT's house but he was no longer there so the passport withdrawal letters were deposited in the local RT and RW. Apart from withdrawing the passport, Joni also said that from the 27th until that day, it was confirmed that DT was on the wanted list or DPO. More details can be seen in data number (5) below.

(5) Right, 23 is out, right? That means there are 5 days, yes. On the 27th, we withdrew his passport. We immediately went to the house in question in Simprug, it was empty. We submitted the letter to the RT and RW. That's a withdrawal, according to the terms. Three days later, we pull it out, we pull it out and there is evidence that we go to the house in question. Then, from the 27th until today, we will check to confirm, check and recheck, whether in the central system it is a DPO and indeed a DPO counter. Earlier, at Soetta Airport, we sent a team, to Halim we sent... sent... sent a team. Later, sir, yes. And witnessed by Angkasapura 2 and from the authorities who were there to witness and indeed they were, yes. (Joni Ginting)

In the narrative above, Joni Ginting acknowledges that the DT passport, which had been issued on July 23, 2020, was withdrawn on July 27, 2020. The entire series of events or chronology presented by Joni Ginting was interrelated without any blemish or extraordinary events. order. Joni seems to have a high commitment in conveying the narrative of his confession. This shows a high level of honesty in the narrative.

In several forensic text narratives in the special fugitive scandal, there are several types of forensic texts of confessions with a low level of honesty based on the aspects of the sequence of events shown in data number (6). In data number (6), it is shown that there is a sequence of events in the narrative of Anita Kolopaking's confession. This can be seen through the chronology of the DT plan for making the e-KTP.

In the Indonesia Lawyers Club talk show, DT's lawyer, Anita Kolopaking, explained her conversation with the Lurah of South Grogol regarding the plan to make her client's eKTP. Anita said that she called the Lurah of South Grogol and asked if DT could extend her KTP or not. After checking, the Lurah of South Grogol told Anita that DT could extend the e-KTP. Clearly, it can be seen in the following data (6).

(6) Whereas, regarding earlier, my application for an ID card called as usual, sir. That's a natural thing, I called the Lurah, "Sir, can Djoko Tjandra be able to extend his 
KTP?" Because his KTP is 2009, sir. "Okay, ma'am, I'll check," he said. After checking, he said, "Oh, okay, ma'am. Please, Pak Djoko, just take a photo to get an E-KTP". And the data is still.. (Anita Kolopaking)

The confession conveyed in the narrative is about DT's plan to make e-KTPs. Anita explained the chronology when she called the Lurah of South Grogol. There are several phrases that can be highlighted in the above narrative. First, the phrase That's a natural thing. What is the purpose of the narrator inserting the phrase in the middle of the chronology presented? Apart from convincing the listeners that what Anita did was a natural thing. Second, the phrase Because the ID card is 2009, sir. What is the importance of the information inserted between the sequence of events? Except to dispel public suspicion that DT extended his KTP to fulfill the administrative requirements for registering a case review. The two inserted phrases are an indication that something is hidden behind the narration conveyed by the narrator. This makes the narrator have low commitment in the narrative.

\section{Honesty in Language Based on Aspects of the Association of Narrator with Events in the Special Fugitive Scandal}

In several forensic text narratives in the special fugitive scandal, there are several types of confession forensic texts with a high level of honesty based on the aspect of the association of narrator with events shown in data number (7). The data shows that there are categories of pronoun use in Anita Kolopaking's confession narrative. This can be seen through the use of the third person pronoun, he, which is conveyed in the narrative.

In the talk show Indonesia Lawyers Club, Anita explained the reason DT entered Indonesia. He said that DT came to Indonesia because he wanted to register for a case review and could not be represented. Anita continued that when DT arrived in Indonesia, she was called by her client to take her to court. Anita also said it was not on her mind that DT was a fugitive. It is clearly seen in the following data (7).

(7) He came to Indonesia because it was a condition rather than a pk application, must be present. So, I did say, "Present, sir, because there must be no other condition is to be present to meet the provisions of SEMA law". When he arrived, he said, "I am. Anita, I can take me at home to GO to PN?", "Ready, sir". I invited him with the intention that there was no thought that he had entered meant he was free to go in and out, dong. (Anita Kolopaking)

In the narration above, Anita Kolopaking confessed that she picked up and took DT to court to register a judicial review (PK) of his case. We can assess the narrative through the category of using pronouns. Anita uses six pronouns or personal pronouns to refer to her client. The six pronouns have a consistent form, namely he. The consistency shown by Anita in her narrative also shows Anita's high commitment in conveying her narrative.

In addition to narratives with a high level of honesty in the special fugitive scandal, there are also several types of forensic confessional texts with a low level of honesty based on the aspect of association of narrator with events shown in data number (8). In the data, it can be seen that there is a category of using pronouns in Anita Kolopaking's confession narrative. This can be seen through the use of the third person pronoun, namely he, which is conveyed in the narrative.

When explaining about the conversation between him and his client via telephone about the plan to pick up DT, Anita Kolopaking was asked by Karni Ilyas what day Anita was called by her client. Anita then answered she was called by DT on Sunday. Then, Anita continued to 
explain that she and her team did pick up DT because they thought there was no problem and anyone could be picked up. It can clearly be seen in the following data (8).

(8) Karni Ilyas: What day is that? Sunday?

Anita K.: Senen, sir.

Karni Ilyas: No, she called mom on Sunday?

Anita K.: Ee.. Sunday. He called, telling me that, "I'm already in Jakarta. Please invite me, we'll go to court together." So, my team was on court at that time, yes. So, I picked up, indeed I picked up because I think it's mediocre to pick up people, who can be picked up, dong.

In the above narration, Anita Kolopaking confesses that she was called by DT on Sunday to discuss her plan to return to Indonesia. There is an exaggerated description in the narrative of the confession. The description was said to be redundant because Karni Ilyas only asked what day it was, but Anita answered with a lengthy description with the sentence So, my team was already in court at that time, yes. In the narrative, it is also found the omission of pronouns/pronouns. In the sentence So, I picked up, I did pick up because I thought it was normal to pick people up, Anita did not mention who was picked up. Even though we already know that the person being picked up is her client, omitting the pronoun in the sentence shows that there is doubt or uncertainty about what Anita should convey.

In several forensic text narratives in the special fugitive scandal, there are several types of denial forensic texts with a high level of honesty based on the aspect of association of narrator with events shown in data number (9). In the data, it appears that Anita Kolopaking categorically denies that DT is not a fugitive. This can be seen through his narration which says that the prosecutor has violated two provisions.

At the beginning of the discussion on the Indonesia Lawyers Club talk show, Anita first denied the fugitive status given to her client. He said that his client had been wronged. According to Anita, the prosecutor had violated two provisions. Then, he explained what provisions were violated by the prosecutor. It can be seen clearly in the following data (9).

(9) So, it also means that there is injustice if I say that we know together that prosecutors cannot do PK, yes. As the law is specifically regulated in the Kuhap paragraph, article 263 paragraph 1, yes. There were two who were hacked or run over by prosecutors. One, the legal subject is that the PK applicant is only a convict or heir, yes. The two objects of what, the verdict Release Decision, apart, from all the demands should not be done. So, two verdicts, two subjects and this object have been violated meaning, yes. (Anita Kolopaking)

In the narrative above, Anita Kolopaking denies the fugitive status given to DT. According to Anita, detailed explanations were found in the narrative, namely details of the law related to alleged violations committed by the prosecutor. However, the details conveyed by Anita are very reasonable considering Anita's capacity as a lawyer, of course it is not surprising if she understands this.

In addition to denial narratives with a high level of honesty in the special fugitive scandal, there are also several types of forensic texts of denial with a low level of honesty based on the aspect of association of narrator with events shown in data number (10). In the data, it can be seen that there are excessive details in the narrative of Anita Kolopaking's denial.

In the Indonesia Lawyers Club talk show, when discussing DT's arrival to Indonesia, Karni Ilyas as the discussion guide asked when DT would come to Jakarta. With a little thought,

Copyright $\odot$ 2022, Journal of Asian Multicultural Research for Social Sciences Study, Under the license CC BY-SA 4.0 
Anita Kolopaking as DT's lawyer replied that she did not know when DT would come to Jakarta. Anita then continued that she only knew that DT called her and asked her to pick up DT to register her case review in court in accordance with the PK requirements, namely that the person concerned must come and cannot be represented. More details can be seen in the following data (10).

(10) Karni Ilyas: When did she come to Jakarta?

Anita K.: Well, if you ask when, I don't know, sir. All I know, he calls me, "Nita, I'm home. When did you pick me up? On Monday alone, we go to the court to register my $P K^{\prime \prime}$, in accordance with pk's terms.

The narration above contains Anita Kolopaking's denial that she did not know when her client would come to Jakarta. When asked when DT came to Jakarta, Anita did not immediately answer in a firm and straightforward manner, but seemed to think a little. There is also excessive detail and is considered too far from the question "When will DT come to Jakarta?" These details were made by Anita to avoid Karni Ilyas's question above. Thus, the narrative form shows the low commitment of Anita Kolopaking.

The special fugitive scandal is a legal case that shocked Indonesia in mid-2020. A number of parties involved in this case were frequently asked for their statements, thus giving birth to new evidence in the form of language (both oral and written), so for the purposes of proof a scientific study was needed. This confirms that the phenomenon of the special fugitive scandal is a very appropriate material to be studied in the study of forensic linguistics. This is in line with the opinion of McMenamin \& Choi (2002) which says that forensic linguistics is a linguistic science that is applied with forensic purposes related to legal language. In line with that, Coultrad \& Johnson (2010) stated that forensic linguistics can focus its studies on the language of legal processes and language as evidence, both oral and written.

The narratives conveyed by the related parties or public figures involved in this case show a defensive attitude or in other words the public figures made a number of confessions and denials. It is these two types that are meant by Olsson (2008) that one type of forensic text that can be examined for honesty is the narrative of confession and denial of public figures.

\section{Conclusion}

Based on the results of research and discussion, it is found that there are narratives with a high level of honesty and narratives with a low level of honesty in the special fugitive scandal. The level of honesty in language in special fugitive scandals tends to have a high level of honesty. This study shows how honesty in language in legal cases can be dissected and analyzed with the study of forensic linguistics theory of John Olsson. Thus, it can be said that linguistics, especially forensic linguistics, has an important role in assisting the process of investigating legal cases where the evidence is in the form of language.

\section{References}

Ali, J. H. M. (2020). Forensic Linguistics: A Study in Criminal Speech Acts. Beni-Suef University International Journal of Humanities and Social Sciences, 2(1), 39-65.

Coulthard, M., \& Johnson, A. (Eds.). (2010). The Routledge handbook of forensic linguistics. Routledge.

Galyashina, E. I. (2018). Forensic linguistics in Russia: State of the art and new challenges. Теория и практика судебной экспертизы, 13(4), 28-37. 
Mahsun. (2018). Linguistik Forensik: Memahami Forensik Berbasis Teks dengan Analogi DNA. Rajagrafindo.

McMenamin, G. R., \& Choi, D. (Eds.). (2002). Forensic linguistics: Advances in forensic stylistics. CRC Press.

Meleong, L. J. (1989). Metologi Penelitian Kualitatif. (Edisi revisi ; Cetakan ketiga puluh delapan, Juli 2018). PT Remaja Rosdakarya.

Olsson, J. (2008). Forensic Linguistics (2nd ed). Continuum.

Olsson, J., \& Luchjenbroers, J. (2014). Forensic Linguistics (Third Edition). Bloomsbury.

Rahmat, W. (2015). Bahasa Ancaman dalam Teks Kaba Sabai Nan Aluih Berbasis Pendekatan Linguistik Forensik. Jurnal Arbitrer, 2(1), 81-97. https://doi.org/10.25077/ar.2.1.81-97.2015

Sudaryanto. (1993). Metode dan Aneka Teknik Analisis Bahasa: Pengantar Penelitian Wahana Kebudayaan Secara Linguistik. Duta Wacana University Press.

Walters, K. (2020). 22 Language, the Law, and Forensic Linguistics. The Cambridge Introduction to Applied Linguistics, 325. 